\title{
Obtaining cashew kernel protein concentrate from nut processing by-product and its use to formulate vegetal burger
}

\author{
Obtenção e uso de concentrado proteico de amêndoa de caju a \\ partir de subproduto do processamento da castanha para \\ formulação de hamburguer vegetal
}

\author{
Janice Ribeiro Lima ${ }^{1 *}$ (1), Ídila Maria da Silva Araújo², Cláudia Oliveira Pinto³, \\ Mayara Lima Goiana ${ }^{4}$, Maria do Carmo Passos Rodrigues ${ }^{4}$, Larissa Vieira de Lima ${ }^{4}$ \\ ${ }^{1}$ Embrapa Agroindústria de Alimentos, Laboratório de Leguminosas, Rio de Janeiro/ RJ - Brasil \\ ${ }^{2}$ Embrapa Agroindústria Tropical, Laboratório de Análise de Alimentos (LAA), Fortaleza/CE - Brasil \\ ${ }^{3}$ Embrapa Gado de Leite, Laboratório de Processamento de Alimentos, Juiz de Fora/MG - Brasil \\ ${ }^{4}$ Universidade Federal do Ceará (UFC), Departamento de Ciência e Tecnologia de Alimentos, Fortaleza/CE - Brasil
}

*Corresponding Author: Janice Ribeiro Lima, Embrapa Agroindústria de Alimentos, Laboratório de Leguminosas, Av. das Américas, 29501, CEP: 23020-470, Rio de Janeiro/RJ - Brasil, e-mail: janice.lima@embrapa.br

Cite as: Lima, J. R., Araújo, I. M. S., Pinto, C. O., Goiana, M. L., Rodrigues, M. C. P., \& Lima, L. V. (2021).

Obtaining cashew kernel protein concentrate from nut processing by-product and its use to formulate vegetal burger. Brazilian Journal of Food Technology, 24, e2020232. https://doi.org/10.1590/1981-6723.23220

\begin{abstract}
Broken kernels are among the by-products of processing cashew nuts which have less commercial value. The present work aimed to obtain a cashew kernel protein concentrate from broken kernels, and then characterize it as well as using it in a vegetable burger formulation. The concentrate was obtained by isoelectric precipitation at four different $\mathrm{pHs}$ and subsequent drying. Higher yield was $58.6 \%$ of proteins (pH 4.0 and 4.5$)$. The concentrate showed Water Absorption Capacity (WAC) of $1.85 \mathrm{~mL} / \mathrm{g}$ and Oil Absorption Capacity (OAC) of $1.06 \mathrm{~mL} / \mathrm{g}$, as well as low solubility in aqueous medium and low foaming capacity. The concentrate was used in vegetable burger production as a substitute for soybean protein. The burgers were submitted to sensory evaluation and obtained an average of 6.6 on a nine-point scale, thus being within the acceptance zone. Regarding the purchase intent, $60 \%$ of the judges would probably or would certainly buy the product. Therefore, the cashew kernel protein concentrate can be used as a protein ingredient for food formulation. Producing cashew kernel protein concentrate allows the use of broken kernels generated in the cashew nut industrial process.
\end{abstract}

Keywords: Anacardium occidentale L.; Acid precipitation; Functional properties; Nut; Protein ingredient; Proximate composition.

\section{Resumo}

Amêndoas quebradas estão entre os subprodutos do processamento da castanha de caju e possuem menor valor comercial. O objetivo deste trabalho foi obter um concentrado proteico de amêndoas quebradas de castanha de caju, caracterizá-lo e utilizá-lo em uma formulação de hambúrguer vegetal. O concentrado foi obtido por 
precipitação isoelétrica em quatro valores de $\mathrm{pH}$ diferentes com subsequente secagem. O maior rendimento foi de $58,6 \%$ de proteínas nos pHs de 4,0 e 4,5. Quanto à capacidade de absorção de água e de óleo, o concentrado apresentou os seguintes resultados, respectivamente, $1,85 \mathrm{~mL} / \mathrm{a}$ e 1,06 mL/g, assim como baixa solubilidade em meio aquoso e baixa capacidade de formação de espuma. Como uma alternativa ao uso da proteína de soja, o concentrado foi utilizado na fabricação de hambúrgueres vegetais. Esses hambúrgueres foram submetidos à avaliação sensorial e obtiveram média de 6,6 em uma escala de 9 pontos, estando assim dentro da zona de aceitação. Em relação à intenção de compra, $60 \%$ dos provadores declararam que provavelmente ou certamente comprariam o produto. Portanto, o concentrado de amêndoa de castanha de caju pode ser utilizado como um ingrediente proteico para uso na formulação de alimentos. A produção de concentrado proteico de amêndoa de caju permite o uso das amêndoas quebradas geradas no processo industrial da castanha de caju.

Palavras-chave: Anacardium occidentale L.; Precipitação ácida; Propriedades funcionais; Castanha; Ingrediente proteico; Composição centesimal.

\section{Introduction}

The cashew kernel is an especially important product in the international nut market. However, obtaining this product generates up to $40 \%$ of broken kernels (Lima et al., 2017). The process of extracting oil from the broken kernels is being used to enhance its economic value and leads to a flour which is rich in proteins (Aroyeun, 2009). The flour that is obtained from the kernel oil extraction can be used in protein concentrate production, thereby giving a new use to this by-product derived from the cashew nut processing industry.

Vegetable protein extraction can be commercially done by precipitation in acid solutions to obtain concentrates ( $48 \%$ to $70 \%$ protein) or by solubilization in alkaline solutions previous to the acid precipitation to obtain an isolate as the final product ( $85 \%$ to $90 \%$ of protein) (Moure et al., 2006).

The use of cashew kernels to obtain concentrate and isolate proteins has been reported by some authors. Ogunwolu et al. (2009) reported obtaining protein concentrate and isolate by alkaline extraction and isoelectric precipitation, as well as by alkaline extraction and methanol precipitation. Queiroga Neto et al. (2001) reported the functional properties of the protein isolates prepared from raw and heat-processed cashew nut kernels. Bora \& Queiroga Neto (2004) evaluated the effect of salt on the functionality of native and denatured Cashew Nut Protein Isolates (CNPI). Sharma et al. (2010) evaluated the characteristics of proteins obtained by saline extraction from the defatted flour of cashews and other nuts. However, none of these authors reported the process and characteristics of the protein concentrate obtained by only acid precipitation, which is a simpler method for obtaining protein.

Proteins obtained from vegetables can be incorporated into foods to increase their nutritional value and functional properties such as solubility, water and oil absorption capacity, foaming capacity and foam stability (Moure et al., 2006).

The Empresa Brasileira de Pesquisa Agropecuária (Embrapa) developed a vegetable cashew burger formulated with the fiber resulting from juice extraction (Lima et al., 2016). In this formulation the soybean protein was used to increase the amount of protein in the burger, but other sources of proteins can be tested. Therefore, the objective of this work aimed to obtain a protein concentrate from defatted cashew kernel flour and to evaluate its composition, functional properties and its use in formulating vegetal burgers.

\section{Material and methods}

\subsection{Preparation of the protein concentrate}

Broken cashew kernels were obtained from a local industry (Fortaleza, Brazil) and ground (Robot Coupe R502V.V, Vincennes, France). To obtain a flour without oil it was used a Soxhlet apparatus and hexane 
extraction for $10 \mathrm{~h}$. The extraction was followed by heating at $60{ }^{\circ} \mathrm{C}$ for $1 \mathrm{~h}$ for solvent removal, milling and screening through 60 mesh size (Fritsch Pulverisette 19, Idar-Oberstein, German).

Concentrate protein was obtained by isoelectric precipitation. Four $\mathrm{pH}$ levels were tested and the protein content was used to select the best $\mathrm{pH}$. The dried defatted flour was suspended in distilled water at a 1:15 ratio, the $\mathrm{pH}$ was adjusted to the test value (3.0, 3.5, 4.0 or 4.5) using $0.5 \mathrm{M} \mathrm{HCl}$ and stirred for $15 \mathrm{~min}$. The precipitate was separated by centrifuging at $1600 \mathrm{xG}$ for $30 \mathrm{~min}$, dried at $60{ }^{\circ} \mathrm{C}$ for $14 \mathrm{~h}$ and milled again as described earlier. The experiment was performed three times, the proteins $(\mathrm{N}$ x 6.25) were determined (Association of Official Analytical Chemists, 1997) and the results were submitted to Analysis of Variance (ANOVA) and Tukey's test $(\alpha=0.05)$ to compare the mean values (SAS Institute, 2009).

\subsection{Physicochemical analysis}

Defatted cashew kernel flour and cashew kernel protein concentrate obtained in the selected $\mathrm{pH}$ in the previous experiment were analyzed for moisture, ash, lipid, carbohydrate and protein contents $(\mathrm{N} \times 6.25)$ (Association of Official Analytical Chemists, 1997). Analyses were performed three times and the results were submitted to ANOVA and the F-test $(\alpha=0.05)$ was used to compare the mean values (SAS Institute, 2009).

\subsection{Functional properties}

Cashew kernel protein concentrate obtained in the $\mathrm{pH}$ selected in the previous experiment was analyzed for Water Absorption Capacity (WAC) and Oil Absorption Capacity (OAC) (Lin et al., 1974). Medium-sized light textured soybean protein purchased in the local market that was used to formulate the burgers (item 2.4) was also analyzed and used as a reference. Analyses were performed three times and the results were submitted to ANOVA and the F-test $(\alpha=0.05$ ) was used to compare the mean values (SAS Institute, 2009).

Water solubility, foaming capacity and foam stability (Glória \& Regitano-d'Arce, 2000) were analyzed and the results were presented in graphs.

\subsection{Using the cashew kernel protein concentrate in vegetal burger formulation}

Two formulations of vegetal burgers were elaborated. The first formulation was prepared according to Lima et al. (2016) with the use of treated cashew fiber (27.0\%), medium-sized light textured soybean protein (27.0\%), tomato $(16.3 \%)$, onion $(5.5 \%)$, bell pepper $(3.1 \%)$, garlic $(0.9 \%)$, powder pepper $(0.1 \%)$, dehydrated parsley $(0.2 \%)$, salt $(1.2 \%)$, corn oil (1.0\%), wheat flour (8.0\%) and water $(9.7 \%)$. The burgers were prepared in $80 \mathrm{~g}$ units. The second formulation was prepared replacing the $27 \%$ of soybean protein by cashew nut concentrate obtained with the $\mathrm{pH}$ selected in the previous experiment. Burgers from both formulations were stored in a freezer at $-18{ }^{\circ} \mathrm{C}$ after being packed in polyethylene plastic materials.

The burgers were analyzed for moisture, ash, lipid, carbohydrate and protein contents (Association of Official Analytical Chemists, 1997). It was also calculated their energy value by the use of the factors of $4 \mathrm{kcal} / \mathrm{g}$ for carbohydrates and proteins and $9 \mathrm{kcal} / \mathrm{g}$ for lipids (Brasil, 2003). They were also submitted to a sensory acceptance test (Meilgaard et al., 2006) performed with 50 judges to access their reasonable level of liking for the burgers. It was used a 9-point structured hedonic scale, ranging from 1 (I disliked it very much) to 9 (I liked it very much). The judges were also questioned about their intent to purchase the burgers using a 5-point structured scale ranging from 1 (I certainly would not buy it) to 5 (I certainly would buy it). The burgers were prepared for the sensory tests on a non-stick frying pan with corn oil added $(10 \mathrm{~mL})$ and heated for $5 \mathrm{~min}$. The burgers were served to the judges in white plates coded with random three-digit numbers. The results were presented as histograms of frequency. Sensorial tests protocols were previously approved by the Research Ethics Committee of the Ceará State University (number 147.279). 


\section{Results and discussion}

\subsection{Physicochemical and functional properties}

Cashew kernels concentrate with higher protein content was obtained by precipitation in $\mathrm{pH} 4.0$ and 4.5 (Table 1). This $\mathrm{pH}$ range was also used to obtain protein concentrates from black beans (Ribeiro et al., 2009), baru almonds (Guimarães et al., 2012), Brazil nuts (Glória \& Regitano-d'Arce, 2000) and cashew nuts (Ogunwolu et al., 2009).

Table 1. Protein content of cashew kernel concentrate obtained in different $\mathrm{pH}(\mathrm{mean} \pm \mathrm{sd}, \mathrm{n}=3)$.

\begin{tabular}{cc}
\hline $\mathbf{p H}$ & Protein (\%) \\
\hline 3.0 & $56.1 \pm 0.7^{\mathrm{c}}$ \\
\hline 3.5 & $57.2 \pm 1.1^{\mathrm{bc}}$ \\
\hline 4.0 & $58.6 \pm 0.4^{\mathrm{a}}$ \\
\hline 4.5 & $58.3 \pm 0.8^{\mathrm{ab}}$ \\
\hline
\end{tabular}

In the column, averages sharing the same letters, are not significantly different (Tukey's test, $\alpha=0.05$ ).

The concentration process by isoelectric precipitation led to a concentrate with $58.6 \%$ of total proteins (Table 2). This value corresponds to a $29.9 \%$ increase in the originally protein content in the defatted flour. Although there are no specific limits for kernels protein concentrates in Brazilian legislation, there is a limit for protein products in general, which is at least $40 \%$ (Brasil, 2005). The concentration process did not affect the lipid content of the defatted flour but led to a concentrate with less carbohydrates and ashes than the flour, probably due to the solubilization of these components in water during the precipitation process. The protein content obtained was similar to a Brazil nut concentrate with $59.3 \%$ of proteins described by Glória \& Regitano-d'Arce (2000), and higher than cupuaçu (Theobroma grandiflorum (Willd. ex Spreng.) K. Schum.) concentrate with $31.1 \%$ of proteins described by Carvalho et al. (2009), both obtained by isoelectric precipitation.

Table 2. Proximate composition of defatted cashew kernel flour and cashew kernel protein concentrate (mean $\pm \mathrm{sd}$, $\mathrm{n}=3$ ).

\begin{tabular}{ccc}
\hline Components (\%) & Defatted flour & Protein concentrate \\
\hline Dry solids & $94.5 \pm 0.3^{\mathrm{a}}$ & $93.1 \pm 0.2^{\mathrm{b}}$ \\
\hline Ashes* & $4.9 \pm 0.0^{\mathrm{a}}$ & $1.9 \pm 0.2^{\mathrm{b}}$ \\
\hline Lipids* $^{*}$ & $2.9 \pm 0.1^{\mathrm{a}}$ & $2.8 \pm 0.0^{\mathrm{a}}$ \\
\hline Proteins* $^{*}$ & $45.1 \pm 0.1^{\mathrm{b}}$ & $58.6 \pm 0.4^{\mathrm{a}}$ \\
\hline Carbohydrates* $^{\mathrm{b}}$ & $47.1 \pm 0.1^{\mathrm{a}}$ & $36.7 \pm 0.4^{\mathrm{b}}$ \\
\hline
\end{tabular}

*Dry basis. In each row, averages sharing the same letters are not significantly different ( $\mathrm{F}$ test, $\alpha=0.05$ ).

The WAC of the cashew kernel concentrate was $1.85 \mathrm{~mL} / \mathrm{g}$ (Table 3). The WAC of proteins is influenced by different parameters such as shape, steric factors, conformational characteristics, hydrophilic-hydrophobic balance of amino acids in the protein molecules as well as the components of the food matrix like lipids, carbohydrates and tannins (Adiamo et al., 2015). The high water absorption capacity presented by the cashew kernel concentrate may be related to its carbohydrates content since these compounds contain starch which can gelatinize and enhance the water holding capacity (Elleuch et al., 2011, Wang et al., 2006). The WAC of cashew kernel concentrate was lower than the results observed for soy protein used as a reference but similar 
to those observed for cashew kernel concentrate $(1.74 \mathrm{~mL} / \mathrm{g}$ ) (Ogunwolu et al., 2009), baru nut concentrate

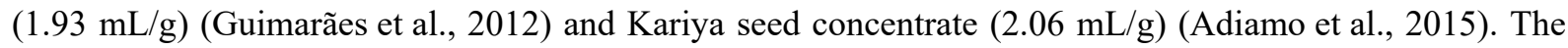
WAC is important in protein concentrates, especially for manufacturing foods like soups and baked products.

Table 3. Water Absorption Capacity (WAC) and Oil Absorption Capacity (OAC) of cashew kernel protein concentrate (mean $\pm \mathrm{sd}, \mathrm{n}=3$ ).

\begin{tabular}{ccc}
\hline Determination $(\mathbf{m L} / \mathbf{g})$ & Protein concentrate & Soy protein (reference) \\
\hline Water Absorption Capacity & $1.85 \pm 0.03^{\mathrm{b}}$ & $2.58 \pm 0.08^{\mathrm{a}}$ \\
\hline Oil Absorption Capacity & $1.06 \pm 0.06^{\mathrm{b}}$ & $1.19 \pm 0.03^{\mathrm{a}}$ \\
\hline
\end{tabular}

In each row, averages sharing the same letters are not significantly different ( $\mathrm{F}$ test, $\alpha=0.05$ ).

The result of OAC $(1.06 \mathrm{~mL} / \mathrm{g})$ (Table 3) was lower than the value observed for soy protein used as a reference and the reported for Brazil nut concentrate $(1.45 \mathrm{~mL} / \mathrm{g})$ (Glória \& Regitano-d'Arce, 2000). However, the concentrate can practically absorb its own weight in oil, which is an important characteristic because oil can retain flavors and increase the mouthfeel of foods (Aremu et al., 2007), and is useful in manufacturing sausages, for example (Ogunwolu et al., 2009).

The minimum solubility of the cashew kernel concentrate was almost $0 \%$ at $\mathrm{pH} 4$, while the maximum solubility was $50 \%$ at $\mathrm{pH} 12.0$ (Figure 1). The minimum solubility close to the isoelectric point could be a result of net charge of peptides, and the surface hydrophobicity which leads to the aggregation and precipitation via hydrophobic interactions (Adiamo et al., 2015, Sorgentini \& Wagner, 2002). The obtained maximum solubility values were similar to the values reported for walnut protein concentrate $(47.54 \%)$ at pH 12.0 (Mao \& Hua, 2012), but smaller than that reported for Brazil nut concentrate (86.8\%) at pH 12.0 (Glória \& Regitano-d'Arce, 2000). Low solubility in the acid pH range of the cashew kernel concentrate indicates its use for producing semi-solid foods such as yogurt, or solid foods such as pasta and other baked products.

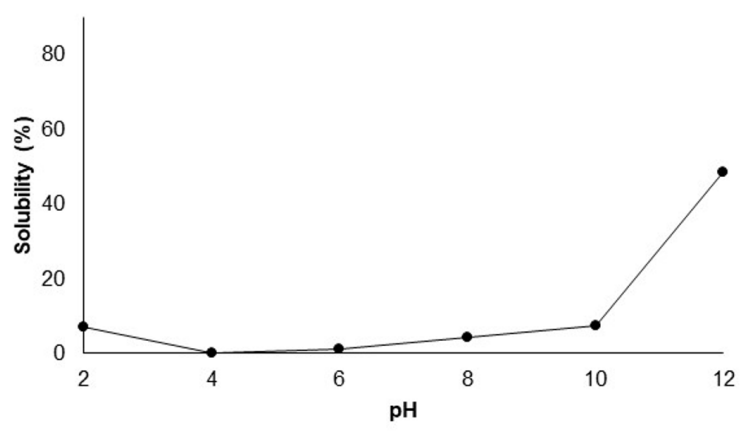

Figure 1. Protein solubility of cashew kernel protein concentrate as a function of $\mathrm{pH}$.

The foaming capacity at the initial time was less than $2 \%$ (Figure 2) and moved to zero in five minutes. Protein foaming property refers to the formation of a film between gas and liquid. The presence of sugars, salts and lipids can impair the formation of foam, as it increases the stability of the protein structure, decreasing their ability of adsorption in the air-water interface (Damodaran et al., 2010). The presence of lipids in the cashew kernel protein concentrate was $2.8 \%$ which can reduce the foaming of proteins, as they have few cohesive and viscoelastic properties that are necessary for forming bubbles (Damodaran et al., 2010). Therefore, the low foaming formation capacity and stability exhibited by the cashew kernel protein concentrate limit its use as a foaming agent in aerated produts like mousses and ice creams. 


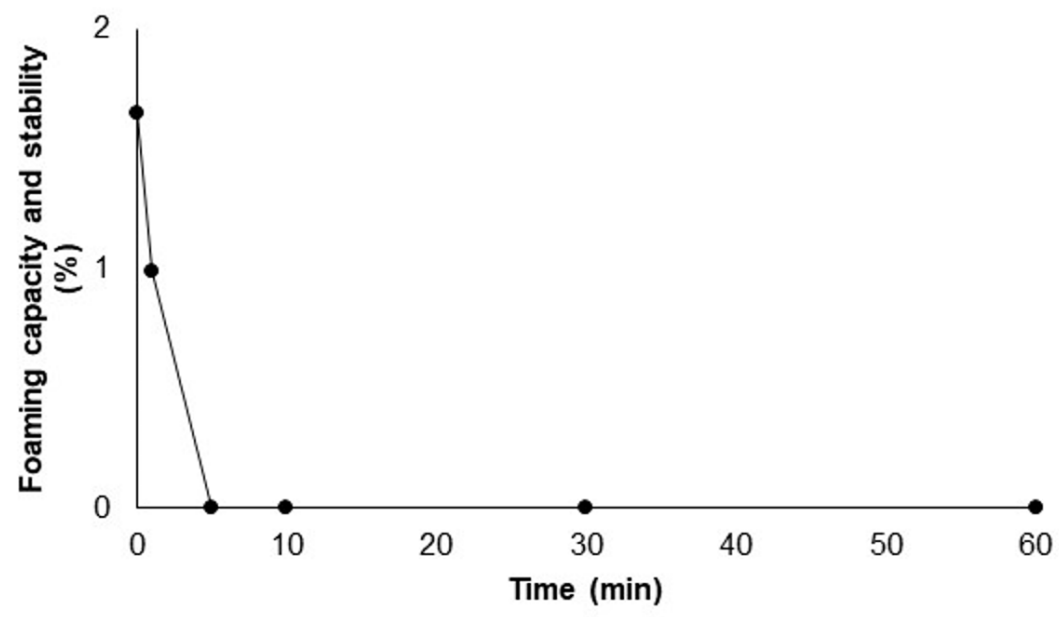

Figure 2. Foaming capacity and stability (\%) of cashew kernel protein concentrate as a function of time.

\subsection{Vegetal burger formulation}

The two burgers showed high moisture and carbohydrate contents and low lipid content (Table 4). Burgers elaborated with cashew kernel concentrate presented higher moisture and protein content than the burger with soybean protein, as well as lower carbohydrates, ashes and energy value than the other formulation.

Table 4. Proximate composition of vegetal burgers made with cashew kernel protein concentrate and soybean protein (mean $\pm \mathrm{sd}, \mathrm{n}=3$ ).

\begin{tabular}{ccc}
\hline Components & Soybean protein burger & Cashew kernels concentrate burger \\
\hline Moisture (\%) & $70.3 \pm 0.6^{\mathrm{b}}$ & $71.4 \pm 0.7^{\mathrm{a}}$ \\
\hline Ashes (\%) & $2.1 \pm 0.1^{\mathrm{a}}$ & $1.3 \pm 0.1^{\mathrm{b}}$ \\
\hline Lipids (\%) & $1.3 \pm 0.2^{\mathrm{a}}$ & $1.5 \pm 0.2^{\mathrm{a}}$ \\
\hline Proteins (\%) & $6.7 \pm 0.7^{\mathrm{b}}$ & $7.1 \pm 0.4^{\mathrm{a}}$ \\
\hline Carbohydrates (\%) & $19.6 \pm 1.6^{\mathrm{a}}$ & $18.7 \pm 1.8^{\mathrm{a}}$ \\
\hline Total energy value (kcal/100 g) & $118.0 \pm 1.1^{\mathrm{a}}$ & $115.4 \pm 2.3^{\mathrm{b}}$ \\
\hline
\end{tabular}

In each row, averages sharing the same letters are not significantly different ( $\mathrm{F}$ test, $\alpha=0.05$ ).

The two burgers formulations tested showed low energy values. The burger portion with the added cashew kernel concentrate $(80 \mathrm{~g})$ showed $92.3 \mathrm{kcal}$, which corresponds to only $4.6 \%$ of the recommended daily calories $(2000 \mathrm{kcal})$ (Brasil, 2003). Furthermore, traditional burgers made with beef have around $170 \mathrm{kcal}$ in a portion of $80 \mathrm{~g}$ (Universidade Estadual de Campinas, 2011) which is $84 \%$ more calories than the vegetal burger made with added cashew kernel concentrate. Thus, the physicochemical composition and total energy values showed by the burger elaborated with cashew kernel concentrate indicate its consumption by persons with calorie restriction.

Regarding sensory acceptance, $72 \%$ of the hedonic scores (Figure 3) for the soybean protein burger and $80 \%$ for the cashew kernel concentrate burger were within the acceptance zone of the scale, between the evaluation of "like slightly" to "extremely like". Moreover, $55 \%$ of the judges said that they would buy or certainly would buy the burgers made with soybean protein and $60 \%$ for the cashew kernel concentrate burger when asked about their purchase intent (Figure 4). 


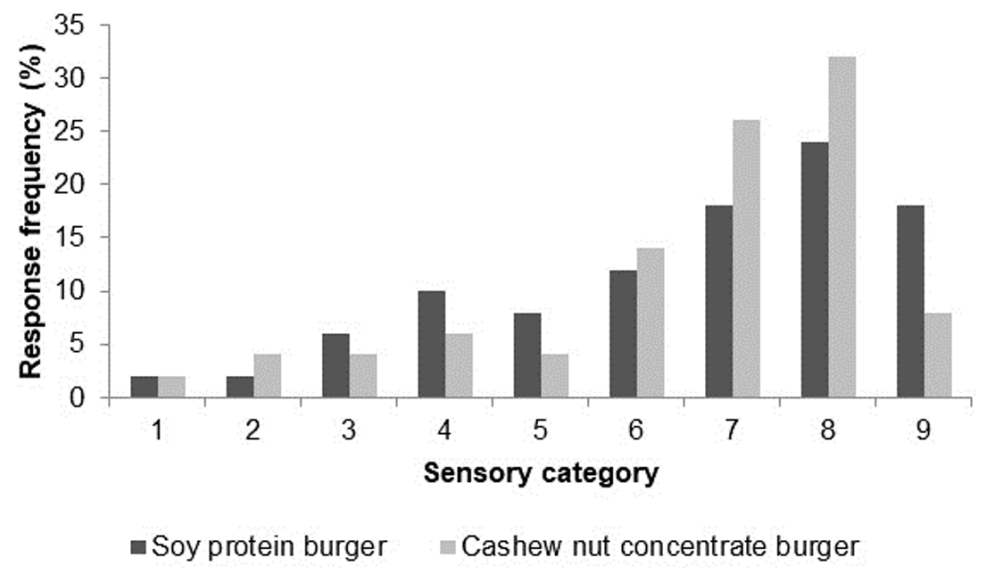

Figure 3. Histograms of frequency for the sensory acceptance of burgers made with soybean proteins and with cashew kernel concentrate proteins. (1) Dislike extremely, (2) dislike very much, (3) dislike moderately, (4) dislike slightly, (5) neither like nor dislike, (6) like slightly, (7) like moderately, (8) like very much, (9) like extremely.

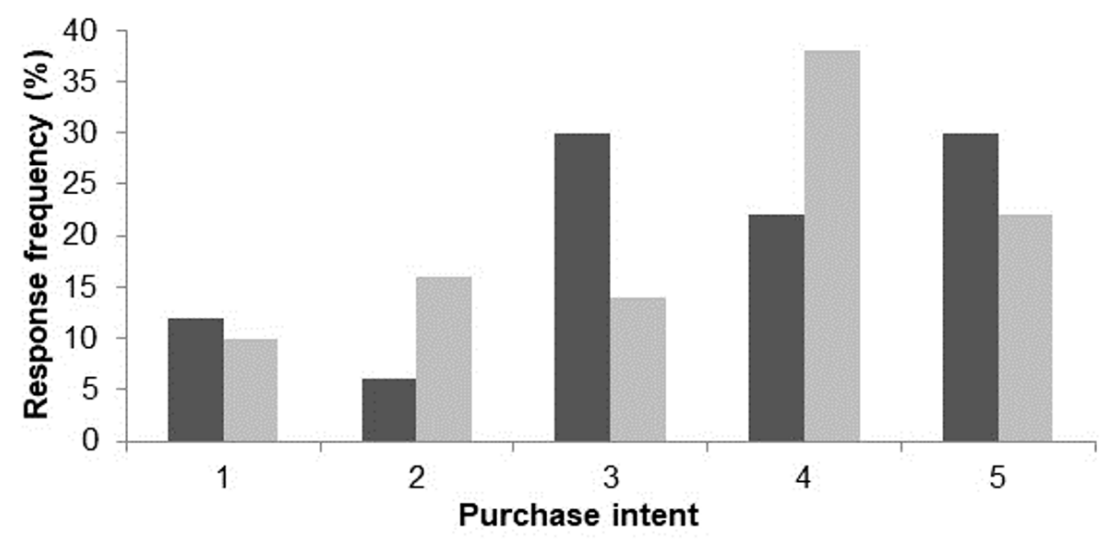

घ Soy protein burger $\quad$ Cashew nut concentrate burger

Figure 4. Histograms of frequency for the purchase intent of burgers made with soybean proteins and with cashew kernel concentrate proteins. (1) I certainly would not buy it, (2) I probably would not buy it, (3) I'm not sure if I would or would not buy it, (4) I would probably buy it, (5) I certainly would buy it).

The sensory acceptance mean values for the two burgers formulations were 6.6 on a nine-point scale, so it can be concluded that the cashew kernel concentrate protein can replace the soybean protein in the burger formulations.

\section{Conclusions}

Cashew kernels concentrate with $58.6 \%$ protein can be obtained by isoeletric precipitation at the $\mathrm{pH}$ range of 4.0 to 4.5. The obtained concentrate had both high Water Absorption Capacity, Oil Absorption Capacity and low water solubility in the acid $\mathrm{pH}$ range, low foaming formation capacity and low foaming stability. The sensory hedonic values for burgers formulated with the cashew kernels protein concentrate were high. The functional properties exhibited by cashew kernels protein concentrate and the sensory acceptance of the burgers made with its incorporation showed that the concentrate may be a good source of protein ingredient regarding food formulations. Therefore, the cashew kernel protein concentrate is another way to use the broken kernels generated in the cashew nut industrial process. 


\section{References}

Adiamo, O. Q., Gbadamosi, O. S., \& Abiose, S. H. (2015). Functional properties and protein digestibility of protein concentrates and isolates produced from kariya (Hildergadia bateri) seed. Journal of Food Processing and Preservation, 40(5), 979-989. http://dx.doi.org/10.1111/jfpp.12678

Aremu, M. O., Olaofe, O., \& Akintayo, E. T. (2007). Functional properties of some Nigerian varieties of legume seed flours and flour concentration effect on foaming and gelling properties. Journal of Food Technology, 5, 109-115. Retrieved in 2020, September 22, from http://medwelljournals.com/abstract/?doi=jftech.2007.109.115

Aroyeun, S. O. (2009). Utilization of cashew kernel meals in the nutritional enrichment of biscuit. African Journal of Food Science, 10, 316-319. Retrieved in 2020, September 22, from http://www.academicjournals.org/ajfs

Association of Official Analytical Chemists - AOAC. (1997). Official methods of analysis (16th ed., 3rd rev). Gaithersburg: AOAC.

Bora, P. S., \& Queiroga Neto, V. (2004). Functionality of native and denatured cashew nut kernel protein isolates at isoelectric $\mathrm{pH}$ as a function of salt concentration. Journal of the Science of Food and Agriculture, 84(15), 2022-2027. http://dx.doi.org/10.1002/jsfa.1905

Brasil. Agência Nacional de Vigilância Sanitária - Anvisa. (2003, dezembro 26). Regulamento técnico sobre rotulagem nutricional de alimentos embalados (Resolução da Diretoria Colegiada - RDC n 360, de 23 de dezembro de 2003). Diário Oficial [da] República Federativa do Brasil, Brasília. Retrieved in 2020, September 22, from

http://portal.anvisa.gov.br/documents/33880/2568070/res0360_23_12_2003.pdf/5d4fc713-9c66-4512-b3c1-afee57e7d9bc

Brasil. (2005, setembro 23). Regulamento técnico para produtos proteicos de origem vegetal (Resolução de Diretoria Colegiada - RDC No 268, de 22 de setembro de 2005). Diário Oficial [da] República Federativa do Brasil, Brasília. Retrieved in 2020, September 22, from http://portal.anvisa.gov.br/documents/33880/2568070/RDC_268_2005.pdf/60145a2f-eb4c-4911-b1e046d776357a25

Carvalho, A. V., García, N. H. P., Farfán, J. A., \& Wada, J. K. A. (2009). Caracterização de concentrado e isolado proteico extraído de sementes de cupuaçu (Theobroma grandiflorum, Schum). Brazilian Journal of Food Technology, 12(1), 1-8. http://dx.doi.org/10.4260/BJFT2009346

Damodaran, S., Parkin, K. L., \& Fennema, O. R. (2010). Química de los alimentos de Fennema (3. ed.). Zaragoza: Acribia.

Elleuch, M., Bedigian, D., Roiseux, O., Besbes, S., Blecker, C., \& Attia, H. (2011). Dietary fibre and fibre-rich by-products of food processing: Characterization, technological functionality and commercial applications: A review. Food Chemistry, 24(2), 411421. http://dx.doi.org/10.1016/j.foodchem.2010.06.077

Glória, M. M., \& Regitano-d’Arce, M. A. B. (2000). Concentrado e isolado proteico de torta de castanha do pará: Obtenção e caracterização química e funcional. Food Science and Technology, 20(2), 240-245. http://dx.doi.org/10.1590/S010120612000000200019

Guimarães, R. C. A., Favaro, S. P., Viana, A. C. A., Braga Neto, J. A., Neves, V. A., \& Honer, M. R. (2012). Study of the proteins in the defatted flour and protein concentrate of baru nuts (Dipteryx alata Vog). Revista Ciência e Tecnologia de Alimentos, 32(3), 464-670. http://dx.doi.org/10.1590/S0101-20612012005000065

Lima, J. R., Garruti, D. S., Bruno, L. M., Araújo, I. M. S., Nobre, A. C. O., \& Garcia, L. G. S. (2017). Replacement of peanut by residue from the cashew nut kernel oil extraction to produce a type paçoca candy. Journal of Food Processing and Preservation, 41(2), e12775. http://dx.doi.org/10.1111/jfpp.12775

Lima, J. R., Garruti, D. S., Pinto, G. A. S., Magalhães, H. C. R., \& Machado, T. F. (2016). Vegetal burgers of cashew fiber and texturized soy protein. Revista Brasileira de Fruticultura, 39(3), e-76. http://dx.doi.org/10.1590/0100-29452017376

Lin, M. J. Y., Humbert, E. S., \& Sosulski, F. W. (1974). Certain functional properties of sunflower meal product. Journal of Food Science, 39(2), 368-370. http://dx.doi.org/10.1111/j.1365-2621.1974.tb02896.x

Mao, X., \& Hua, Y. (2012). Composition, structure and functional properties of protein concentrates and isolates produced from walnut (Juglans regia L.). International Journal of Molecular Sciences, 13(2), 1561-1581. PMid:22408408. http://dx.doi.org/10.3390/ijms13021561

Meilgaard, M. C., Carr, B. T., \& Carr, B. T. (2006). Sensory evaluation techniques. New York: CRC. http://dx.doi.org/10.1201/b16452

Moure, A., Sineiro, J., Domínguez, H., \& Parajó, J. C. (2006). Functionality of oilseed protein products. A review. Food Research International, 39(9), 945-963. http://dx.doi.org/10.1016/j.foodres.2006.07.002

Ogunwolu, S. O., Henshaw, F. O., Mock, H. P., Santros, A., \& Awonorin, S. O. (2009). Functional properties of protein concentrates and isolates produced from cashew (Anacardium occidentale L.) nut. Food Chemistry, 115(3), 852-858. http://dx.doi.org/10.1016/j.foodchem.2009.01.011

Queiroga Neto, V., Narain, N., Silva, J. B., \& Bora, P. S. (2001). Functional properties of raw and heat processed cashew nut (Anacardium occidentale, L.) kernel protein isolates. Die Nahrung, 45(4), 258-262. PMid:11534465. http://dx.doi.org/10.1002/1521-3803(20010801)45:4<258::AID-FOOD258>3.0.CO;2-3

Ribeiro, H. J. S. S., Prudencio, S. H., Miyagui, D. T., \& Ribeiro, E. L. A. (2009). Caracterização de concentrado proteico de feijão comum preto, cultivar lapar 44, novo e envelhecido. Food Science and Technology, 29(3), 571-580. http://dx.doi.org/10.1590/S0101-20612009000300019

SAS Institute. (2009). Statistical analysis system user's guide. Cary, NC: SAS Institute. 
Obtaining cashew kernel protein concentrate from nut processing by-product and its use to formulate vegetal burger

Lima, J. R. et al.

Sharma, G. M., Su, M., Joshi, A. U., Roux, K. H., \& Sathe, S. K. (2010). Functional properties of selected edible oilseeds proteins. Journal of Agricultural and Food Chemistry, 58(9), 5457-5464. PMid:20201552. http://dx.doi.org/10.1021/jf1002446

Sorgentini, D. A., \& Wagner, J. R. (2002). Comparative study of foaming properties of whey and isolate soy bean proteins. Food Research International, 35(8), 721-729. http://dx.doi.org/10.1016/S0963-9969(02)00067-4

Universidade Estadual de Campinas - UNICAMP. (2011). TACO: Tabela Brasileira de Composição de Alimentos. Campinas. Retrieved in 2020, September 22, from

http://www.unicamp.br/nepa/taco/contar/taco_4_edicao_ampliada_e_revisada.pdf?arquivo=taco_4_versao_ampliada_e_revisad a.pdf

Wang, S. H., Rocha, G. O., Nascimento, T. P., \& Ascheri, J. L. R. (2006). Absorção de água e propriedades espumantes de farinhas extrusadas de trigo. Food Science and Technology (Campinas), 26(2), 457-481. http://dx.doi.org/10.1590/S010120612006000200035

Funding: None.

Received: Sept. 22, 2020; Accepted: Mar. 01, 2021 